\title{
CHAPTER 17: SIMULTANEOUS DETERMINATION OF ALIPHATIC ORGANIC ACIDS AND AMINO ACIDS IN FLORAL HONEY: ANALYTICAL VALIDATION IN CAPILLARY ELECTROPHORESIS
}

Greici Bergamo $^{1}$; Siluana Katia Tischer Seraglio ${ }^{2}$; Clara Mariana Gonçalves Lima ${ }^{3}$, Roseane Fett ${ }^{4}$; Ana Carolina Oliveira Costa $^{5}$

\begin{abstract}
Few studies investigated low molecular mass aliphatic organic acids (AOA) and amino acids in honey mainly due to their low concentrations in this product. However, these compounds influence the physical, chemical, sensorial, and biological characteristics of honey and their investigation by validated methods are important to guarantee the veracity of these data. Thus, this study aimed to validate a simultaneous method for determination of 13 AOA and two amino acids in floral honey using a capillary electrophoresis system equipped with diode array detector. The proposed method was validated based on Eurachem and Ministry of Agriculture, Livestock, and Food Supply Guidelines, which showed good results for the evaluated validation parameters: system suitability, limits of detection and quantification, linearity, matrix effect, precision, and accuracy. Also, the Peakmaster ${ }^{\circledR}$ software was used to select an appropriate internal standard. The validated method was then employed to determined AOA and amino acids in multifloral honeys, in which citric, glycolic, gluconic, and glutamic acids were quantified in all samples. Therefore, the proposed method can be used in the determination of AOA and amino acids in floral honeys with precision and accuracy ensured.
\end{abstract}

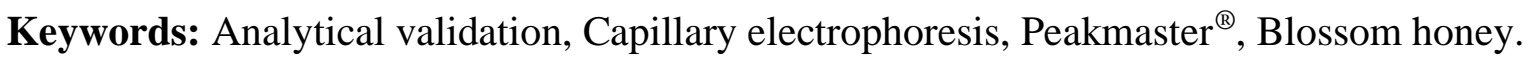

\section{Introduction}

Honey is a product produced by bees, mainly by the genus Apis mellifera, from the nectar of flowers (floral honey); or from secretions of living parts of plants or excretions of plant-sucking insects (honeydew honey) (EUROPEAN COMMISSION, 2002).

Widely consumed due to its sweet taste and its beneficial health properties (BOBIS et al., 2020; DA SILVA et al., 2016; LUKASIEWICZ; KOWALSKI; MAKAREWICZ, 2015; SERAGLIO et al., 2019; TERZO; MULÈ; AMATO, 2020), many researches have been dedicated to investigate the physicochemical properties and composition of honey, such as carbohydrate contents, free acidity, minerals, proteins, phenolic compounds, low molecular mass aliphatic organic acids (AOA), and amino acids (AZEVEDO et al., 2017a, 2017b; BERGAMO et al., 2018, 2019; BOBIS et al., 2020; KAYGUSUZ et al., 2016; KOWALSKI et al., 2017; SERAGLIO et al., 2016).

\footnotetext{
${ }^{1}$ Doutora, Ciências dos Alimentos, Universidade Federal de Santa Catarina, greici.bergamo@ hotmail.com

${ }^{2}$ Pós-doutoranda (CNPq Scholarship - Brazil (160175/2019-4)), Ciências dos Alimentos, Universidade Federal de Santa Catarina, siluanaseraglio@hotmail.com

${ }^{3}$ Doutoranda, Ciências dos Alimentos, Universidade Federal de Santa Catarina, claramarianalima@gmail.com

${ }^{4}$ Professora, Doutora em Química Orgânica, Universidade Federal de Santa Catarina, roseane.fett@ufsc.br

${ }^{5}$ Professora, Doutora em Química Analítica, Universidade Federal de Santa Catarina, ana.costa@ufsc.br
} 

However, there are still few studies that investigated AOA and amino acids in honey, and they indicate low concentrations of these constituents, generally around $1 \%$ each. Although the small concentrations, these compounds influence the physical, chemical, sensorial, and biological characteristics of honey (DA SILVA et al., 2016; DEL CAMPO et al., 2016; KOWALSKI et al., 2017; TEZCAN et al., 2011). Thus, the investigation of these compounds in this food is relevant and the use of a validated method guarantees the veracity of these data.

Several techniques coupled with different detectors can be used to evaluate AOA and amino acids in honey, and, among them, high performance liquid chromatography is applied more frequently (HAROUN et al., 2012; KEKE; CINKMANIS, 2019; KOWALSKI et al., 2017). Still, other studies have used gas chromatography coupled with mass spectrometry (AZEVEDO et al., 2017b; SANZ et al., 2005) and capillary electrophoresis coupled with diode array detector (BRUGNEROTTO et al., 2019; MATO et al., 2006b; TEZCAN et al., 2011).

The use of methods based on capillary electrophoresis can be advantageous because it is a versatile analytical technique, capable of detecting compounds with low molar absorption capacity, such as AOA and amino acids, in addition to enabling short-term analysis and simple sample preparation (BRUGNEROTTO et al., 2019; KALJURAND; KOEL, 2011; MATO et al., 2006a). Although this technique shows promising results, the determination of AOA and amino acids by capillary electrophoresis in honeys is very scarce, with few studies exploring this technique (BRUGNEROTTO et al., 2019; MATO et al., 2006b; NAVARRETE et al., 2005; TEZCAN et al., 2011).

Thus, the present study aimed to validate a method for simultaneous determination of AOA and amino acids in floral honey using a capillary electrophoresis system equipped with diode array detector.

\section{Material and Methods}

Reagents

Ultrapure water (Millipore Corporation, Milli-Q Simplicity® UV system, Saverne, France) was used for all analyses. Cetyl trimethylammonium bromide (CTAB), 3,5dinitrobenzoic acid, $\beta$-alanine, trifluoracetic acid (IS - internal standard), and analytical standards of AOA and amino acids (maleic, malonic, tartaric, formic, citric, malic, glycolic, lactic, succinic, acetic, propionic, gluconic, glutaric, aspartic, and glutamic acids) were obtained from Sigma-Aldrich (St. Louis, USA), while sodium hydroxide $(\mathrm{NaOH})$ was acquired from Vetec (Duque de Caxias, Brazil). 
Instrumentation

Simultaneous determination of AOA and amino acids was performed in a capillary electrophoresis system equipped with diode array detector (Agilent Technologies, 7100, Germany) according to Azevedo et al. (2014), with modifications.

Electrophoretic separation was conducted in an uncoated fused-silica capillary (Polymicro Technologies, Phoenix, USA) of $64.5 \mathrm{~cm}$ effective length (73 $\mathrm{cm}$ total length) and $75 \mu \mathrm{m}$ inner diameter at $25^{\circ} \mathrm{C}$. Background electrolyte (BGE) was composed of $21 \mathrm{mmol} \mathrm{L}^{-1}$ $\beta$-alanine, $10 \mathrm{mmol} \mathrm{L}^{-1}$ 3,5-dihydroxybenzoic acid, and 1,5 $\mathrm{mmol} \mathrm{L}^{-1} \mathrm{CTAB}$, at $\mathrm{pH}$ 3.6. At the beginning of each day, capillary was flushed for $10 \mathrm{~min}$ with $1 \mathrm{~mol} \mathrm{~L}^{-1} \mathrm{NaOH}$, followed by water (10 min) and BGE (15 min), while at the end of each working day, it was rinsed with 1 mol L ${ }^{-1} \mathrm{NaOH}$ followed by water, both for $10 \mathrm{~min}$. Hydrodynamic pressure $(+50 \mathrm{mbar}$ for $3 \mathrm{~s})$ was used for the introduction of standards and samples into the capillary by its end furthest from the detector. Separation voltage of $-30 \mathrm{kV}$ was applied, and between runs, capillary was flushed by $1 \mathrm{~min}$ with BGE. The analytes detection was performed by indirect mode (set at 254 $\mathrm{nm}$, with a reference at $360 \mathrm{~nm}$ for peak inversion). Data acquisition and treatment were performed using HP ChemStation software (rev. A.06.01).

\section{Samples}

Five multifloral honeys were harvested by local beekeepers in Urubici, Santa Catarina state, Brazil, in 2016. Honeycombs were manually drained in the laboratory and the honey stored at $-20 \pm 2{ }^{\circ} \mathrm{C}$ until analyses.

Before injection into capillary electrophoresis system, the thawed samples $(1.0 \pm 0.01$ g) were diluted with water in a $5 \mathrm{~mL}$ volumetric flask. This mixture was centrifugated by 14.000 rpm for 10 min (MiniSpin ${ }^{\circledR}$ Plus, Eppendorf AG, Suffolk, USA) and the supernatant diluted in the proportion 9:1 (v/v; supernatant:IS at the concentration of $\left.570 \mathrm{mg} \mathrm{L}^{-1}\right)$. Further dilutions were performed when necessary and the results were expressed in $\mathrm{mg} 100 \mathrm{~g}^{-1}$.

\section{Analytical validation}

The proposed method was validated based on Eurachem and Ministry of Agriculture, Livestock, and Food Supply Guidelines (BRASIL, 2011; MAGNUSSON; ÖRNEMARK, 2014) and included the determination of the system suitability, limits of detection and quantification, linearity, matrix effect, precision, and accuracy.

\section{System suitability}

System suitability was evaluated by 10 consecutives injections of the intermediate concentration of the standard calibration curve. Results were presented as \%RSD (relative 
standard deviation) for corrected peak area and corrected migration time.

\section{Limits of detection and quantification}

Limit of detection (LOD) was considered as the lowest concentration that was possible to detect the analytes (signal/noise ratio $\geq 3$ ), while the limit of quantification (LOQ) was established as the lowest concentration that was possible to quantify the analytes with acceptable precision (signal/noise ratio $\geq 10$ ). Both limits were determined in standard solution, since no matrix effect was found, by six independent replicates in the established concentrations. Results were expressed as $\mathrm{mg} \mathrm{L}^{-1}$.

\section{Linearity and matrix effect}

Two calibration curves, constructed at five concentration levels and in three independent replicates, were prepared to assess the linearity and matrix effect: (a) standard calibration curve in water; and (b) matrix-matched calibration curve applying the method of standard addition, which consist in the fortification of a sample with standard solution.

For both curves, the linear regression model was chosen because it represented the relationship between the analyte concentration and the instrumental signal obtained. Then, ordinary least squares method (OLSM) was used to calculate the intercept and slope, but it assumes some assumptions. Violations of OLSM residuals in relation to their normality, homoscedasticity, and independency were investigated by Shapiro-Wilk test (SHAPIRO; WILK, 1965), Levene test (LEVENE, 1960), and Durbin-Watson test (DURBIN; WATSON, 1950), respectively. Also, $F$-tests were employed to assess the fitting of the model by its regression and lack of fit significances (SNEDECOR; COCHRAN, 1989).

The matrix effect was evaluated by $t$-test comparing the slope of the standard calibration curve and matrix-matched calibration curve, both calculated by OLSM (ARMITAGE; BERRY; MATTHEWS, 2002).

\section{Precision}

For repeatability (intra-day precision), three independent replicates of all concentration levels of the standard calibration curve were prepared by the same analyst and injected on the same day. For partial reproducibility (inter-day precision), this same procedure was performed over three different days by different analysts $(n=9)$. Results were presented in terms of \%RSD for corrected peak area.

\section{Accuracy}

Apparent accuracy was evaluated by the injection of six independent replicates of a fortified sample at three concentration levels of the calibration curve (low, medium, and high). The $\%$ recovery was calculated as shown in Equation 1, and the concentrations used in the 
formula were estimated using the standard calibration curve.

$\%$ recovery $=\left(\frac{\text { concentration in the fortified sample-concentration in the non fortified sample }}{\text { concentration added }}\right) \times 100 \quad$ Equation 1

\section{Data analysis}

Differences were considered statistically significant at the 5\% level $(p<0.05)$ and data processing was performed using the software's Statistica ${ }^{\circledR}$ (version 13.0) and Past ${ }^{\circledR}$ (version 4.02).

\section{Results and Discussion}

Considering the impact of AOA and amino acids on the honey composition (DE-MELO et al., 2018; DEL CAMPO et al., 2016; KOWALSKI et al., 2017), their investigation is relevant and the use of a validated method ensures the trueness of these data.

In this sense, according to the intrinsic characteristics of honey, it was necessary to make changes in the method, which was originally developed and validated for the evaluation of AOA in sugarcane spirits. Thus, considering reports in the literature for floral honey (BRUGNEROTTO et al., 2019; DEL CAMPO et al., 2016; KEKE; CINKMANIS, 2019; KOWALSKI et al., 2017; SUN et al., 2017), new AOA (gluconic, glutaric, and propionic acids) and two amino acids (aspartic and glutamic acids) were also investigated by this method. This change resulted in the search for a new IS, a function previously designated by aspartic acid and now by trifluoroacetic acid. This IS was selected using the Peakmaster ${ }^{\circledR}$ software, in which was possible to simulate an electropherogram with the presence of many compounds (data not shown).

Another important change made in the method was the inversion of the electroosmotic flow inside the capillary through the use of CTAB, an electroosmotic flow invertor, in the BGE solution instead the capillary modification by applying a semi-permanent coating of 2hydroxypropyltrimethyl-ammonium chloride chitosan, as originally proposed. This procedure facilitated and reduced the time of pre-analysis operations.

\section{Method validation}

Suitability tests are important to ensure that instrumental system that will be used is providing reproducible data. In this study, it was evaluated by consecutive injections of the 
same concentration of standard mixture. As shown in Table 1, low \%RSD values were found, ranging from 0.6 to $1.3 \%$ for the corrected peak area and from 0.1 to $0.3 \%$ for corrected migration time. These results indicate that the validation procedure can continue since the instrumental system is suitable.

Table 1. System suitability, limit of quantification (LOQ), limit of detection (LOD), and the concentration range for low molecular mass aliphatic organic acids (AOA) and amino acids.

\begin{tabular}{|c|c|c|c|c|c|}
\hline \multirow[b]{2}{*}{ Compound } & \multicolumn{2}{|c|}{ System suitability } & \multirow[b]{2}{*}{$\begin{array}{c}\text { LOQ } \\
\left(\mathrm{mg} \mathrm{L}^{-1}\right)\end{array}$} & \multirow[b]{2}{*}{$\begin{array}{c}\text { LOD } \\
\left(\mathrm{mg} \mathrm{L}^{-1}\right)\end{array}$} & \multirow{2}{*}{$\begin{array}{l}\text { Concentra- } \\
\text { tion range } \\
\left(\mathrm{mg} \mathrm{L}^{-1}\right)\end{array}$} \\
\hline & $\begin{array}{c}\text { Corrected peak } \\
\text { area (\%RSD) }\end{array}$ & $\begin{array}{l}\text { Corrected migration } \\
\text { time (\%RSD) }\end{array}$ & & & \\
\hline \multicolumn{6}{|l|}{$A O A$} \\
\hline Maleic acid & 0.8 & 0.1 & $7.0 \pm 0.3$ & $1.7 \pm 0.1$ & $7.0-55.7$ \\
\hline Malonic acid & 1.1 & 0.1 & $6.2 \pm 0.2$ & $1.6 \pm 0.1$ & $6.2-49.9$ \\
\hline Tartaric acid & 0.9 & 0.3 & $9.0 \pm 0.4$ & $2.2 \pm 0.1$ & $9.0-72.0$ \\
\hline Formic acid & 1.3 & 0.1 & $2.8 \pm 0.1$ & $0.7 \pm 0.0$ & $2.8-22.1$ \\
\hline Citric acid & 1.0 & 0.2 & $11.5 \pm 0.6$ & $2.9 \pm 0.2$ & $11.5-92.2$ \\
\hline Malic acid & 0.6 & 0.3 & $8.0 \pm 0.4$ & $2.0 \pm 0.1$ & $8.0-64.4$ \\
\hline Glycolic acid & 0.9 & 0.2 & $4.6 \pm 0.2$ & $1.1 \pm 0.0$ & $4.6-36.5$ \\
\hline Lactic acid & 1.2 & 0.1 & $5.4 \pm 0.3$ & $1.3 \pm 0.0$ & $5.4-43.2$ \\
\hline Gluconic acid & 0.7 & 0.1 & $13.1 \pm 0.6$ & $3.3 \pm 0.2$ & $13.1-104.7$ \\
\hline Succinic acid & 1.1 & 0.3 & $7.1 \pm 0.3$ & $1.8 \pm 0.1$ & $7.1-56.7$ \\
\hline Glutaric acid & 0.9 & 0.2 & $7.9 \pm 0.4$ & $2.0 \pm 0.1$ & $7.9-63.4$ \\
\hline Acetic acid & 0.8 & 0.3 & $3.6 \pm 0.2$ & $0.9 \pm 0.0$ & $3.6-28.8$ \\
\hline Propionic acid & 0.7 & 0.2 & $4.4 \pm 0.2$ & $1.1 \pm 0.0$ & $4.4-35.6$ \\
\hline \multicolumn{6}{|l|}{ Amino acids } \\
\hline Aspartic acid & 0.8 & 0.1 & $8.0 \pm 0.4$ & $2.0 \pm 0.1$ & $8.0-63.9$ \\
\hline Glutamic acid & 1.0 & 0.2 & $8.8 \pm 0.4$ & $2.2 \pm 0.1$ & $8.8-70.6$ \\
\hline
\end{tabular}

\%RSD - relative standard deviation. Results expressed as mean \pm standard deviation for LOQ, LOD, and concentration range.

Source: Authors (2020), except the data of concentration range and limits of detection and quantification which were adapted from Seraglio (2020).

In Table 1 were also presented LOQ, LOD, and the concentration range proposed for each compound. For LOQ and LOD, the \%RSD values were lower than $7.0 \%$, results considered satisfactory for indirect methods in capillary electrophoresis system (AZEVEDO et 
al., 2014). Also, these results can be considered adequate for the determination of the investigated compounds in floral honey, since many of these compounds were quantified in the analyzed samples.

Due to the low concentration of many of the investigated compounds and to ensure the maximum dilution of the samples, to decrease the matrix effect, it is important that the calibration curve starts at low concentrations. In this sense, for each compound, the concentration determined as LOQ was established as the first concentration level of the calibration curve.

The concentration range proposed in this study was investigated in relation to its linearity in both calibration curves (standard and matrix-matched). Firstly, the OLSM assumptions were investigated and all them were confirmed. No significant evidence of nonnormality ( $p$ values $>0.05$ ), autocorrelation ( $p$ values $>0.05$ ), and heteroscedasticity ( $p$ values $>0.05$ ) of the residuals were found. In Table 2 , these data are shown for the standard calibration curve.

Table 2. Residuals normality, homoscedasticity, and independency of standard calibration curve and matrix effect for low molecular mass aliphatic organic acids (AOA) and amino acids.

\begin{tabular}{lcccc}
\hline & \multicolumn{3}{c}{ Standard calibration curve } & \\
\cline { 2 - 3 } Compound & $\begin{array}{c}\text { Normality } \\
(p \text { value by } \\
\text { Shapiro-Wilk test })\end{array}$ & $\begin{array}{c}\text { Homoscedasticity } \\
(p \text { value by } \\
\text { Levene test })\end{array}$ & $\begin{array}{c}\text { Independency } \\
(p \text { value by } \\
\text { Durbin-Watson } \\
\text { test })\end{array}$ & $\begin{array}{c}\text { Matrix effect } \\
(p \text { value by } t \text { - } \\
\text { test })\end{array}$ \\
\hline AOA & 0.184 & 0.153 & 0.105 & 0.559 \\
Maleic acid & 0.326 & 0.734 & 0.374 & 0.180 \\
Malonic acid & 0.095 & 0.634 & 0.194 & 0.068 \\
Tartaric acid & 0.491 & 0.648 & 0.083 & 0.524 \\
Formic acid & 0.301 & 0.199 & 0.235 & 0.198 \\
Citric acid & 0.073 & 0.535 & 0.074 & 0.963 \\
Malic acid & 0.396 & 0.178 & 0.092 & 0.291 \\
Glycolic acid & 0.832 & 0.741 & 0.156 & 0.499 \\
Lactic acid & 0.387 & 0.601 & 0.235 & 0.078 \\
Gluconic acid & 0.062 & 0.783 & 0.082 & 0.097 \\
Succinic acid & 0.073 & 0.563 & 0.174 & 0.078 \\
Glutaric acid & & & & \\
\hline
\end{tabular}




\begin{tabular}{lllll}
\hline Acetic acid & 0.892 & 0.489 & 0.293 & 0.485 \\
Propionic acid & 0.204 & 0.273 & 0.093 & 0.931 \\
Amino acids & & & & \\
Aspartic acid & 0.167 & 0.452 & 0.074 & 0.503 \\
Glutamic acid & 0.674 & 0.633 & 0.198 & 0.663 \\
\hline
\end{tabular}

Differences were considered statistically significant at $p<0.05$.

Source: Authors (2020).

The goodness of the linear regression was also confirmed of both curves. The high significance of the regression ( $p$ values $<0.05$ ) and no evidence of lack of fit ( $p$ values $>0.05$ ) indicate the linearity in the concentration range studied. In Table 3, these data are shown for the standard calibration curve.

Therefore, the OLSM can be considerate adequate to predict the concentration of AOA and amino acids in floral honey respecting the concentration range studied.

Table 3. ANOVA statistics for linear regression model of standard calibration curve for low molecular mass aliphatic organic acids (AOA) and amino acids.

\begin{tabular}{|c|c|c|c|c|}
\hline \multirow[b]{2}{*}{ Compound } & \multicolumn{3}{|c|}{ Regression } & \multirow{2}{*}{$\begin{array}{c}\text { Lack of fit } \\
\text { ( } p \text { value by } \\
F \text {-test })\end{array}$} \\
\hline & Equation & $\begin{array}{l}\text { Coefficient of } \\
\text { determination }\end{array}$ & $\begin{array}{c}p \text { value by } \\
F \text {-test }\end{array}$ & \\
\hline \multicolumn{5}{|l|}{$A O A$} \\
\hline Maleic acid & $y=1.678 x-0.010$ & 0.987 & $<0.001$ & 0.805 \\
\hline Malonic acid & $y=1.723 x-0.007$ & 0.998 & $<0.001$ & 0.939 \\
\hline Tartaric acid & $y=3.089 x-0.018$ & 0.999 & $<0.001$ & 0.404 \\
\hline Formic acid & $y=1.727 x-0.001$ & 0.988 & $<0.001$ & 0.589 \\
\hline Citric acid & $y=2.645 x-0.093$ & 0.991 & $<0.001$ & 0.237 \\
\hline Malic acid & $\mathrm{y}=3.032 \mathrm{x}-0.029$ & 0.994 & $<0.001$ & 0.851 \\
\hline Glycolic acid & $y=3.069 x-0.018$ & 0.988 & $<0.001$ & 0.755 \\
\hline Lactic acid & $y=2.282 x-0.010$ & 0.990 & $<0.001$ & 0.598 \\
\hline Gluconic acid & $y=3.252 x-0.014$ & 0.995 & $<0.001$ & 0.901 \\
\hline Succinic acid & $y=3.621 x-0.006$ & 0.999 & $<0.001$ & 0.759 \\
\hline Glutaric acid & $y=4.035 x+0.002$ & 0.991 & $<0.001$ & 0.919 \\
\hline Acetic acid & $y=3.056 x+0.028$ & 0.987 & $<0.001$ & 0.059 \\
\hline
\end{tabular}




\begin{tabular}{llccc}
\hline Propionic acid & $\mathrm{y}=3.334 \mathrm{x}-0.020$ & 0.992 & $<0.001$ & 0.928 \\
Amino acids & & & & \\
Aspartic acid & $\mathrm{y}=3.454 \mathrm{x}+0.002$ & 0.995 & $<0.001$ & 0.467 \\
Glutamic acid & $\mathrm{y}=4.561 \mathrm{x}-0.108$ & 0.994 & $<0.001$ & 0.889
\end{tabular}

Differences were considered statistically significant at $p<0.05$.

Source: Authors (2020).

Once the linearity of both curves was confirmed, matrix effect was investigated. As shown in Table 2, no evidence of matrix effect ( $p$ values $>0.05$ ) was detected in the proposed concentration range. This data suggests that both curves gave the same response. Thus, the standard calibration curve was chosen for the quantification and subsequent validation steps of AOA and amino acids in floral honey.

Considering the data shown in Table 4, it was possible to observe acceptable repeatability and partial reproducibility of the method, which \%RSD values lower than 5.3\%, and satisfactory recovery, ranging from $94.2 \pm 3.1$ to $107.3 \pm 2.1 \%$. These data are important since they reinforce the reliability of the method in relation to the quantification of AOA and amino acids in floral honey.

Table 4. Precision and accuracy of low molecular mass aliphatic organic acids (AOA) and amino acids in the standard calibration curve.

\section{Precision}

Accuracy

Compound

(corrected peak area; \%RSD)

(\% recovery)

Intra-day Inter-day Low level $\begin{gathered}\text { Medium } \\ \text { level }\end{gathered} \quad$ High level

$A O A$

$\begin{array}{llllll}\text { Maleic acid } & 0.5-4.6 & 1.6-4.9 & 102.3 \pm 3.1 & 102.0 \pm 4.5 & 102.7 \pm 4.6 \\ \text { Malonic acid } & 0.7-4.2 & 2.1-5.3 & 105.4 \pm 4.1 & 104.3 \pm 5.0 & 104.5 \pm 2.5 \\ \text { Tartaric acid } & 0.9-3.6 & 1.3-4.2 & 106.5 \pm 2.4 & 104.2 \pm 4.2 & 103.4 \pm 5.3 \\ \text { Formic acid } & 1.1-4.2 & 2.1-4.4 & 102.0 \pm 4.5 & 99.7 \pm 3.4 & 106.3 \pm 3.2 \\ \text { Citric acid } & 0.8-2.7 & 1.4-3.9 & 106.2 \pm 2.1 & 102.1 \pm 3.2 & 105.6 \pm 4.2 \\ \text { Malic acid } & 1.0-3.7 & 1.9-4.8 & 102.6 \pm 5.1 & 101.8 \pm 4.1 & 103.7 \pm 2.9 \\ \text { Glycolic acid } & 0.3-3.1 & 0.9-4.0 & 104.1 \pm 5.2 & 105.1 \pm 4.6 & 101.8 \pm 4.0 \\ \text { Lactic acid } & 1.1-4.4 & 1.7-5.2 & 106.5 \pm 3.4 & 104.3 \pm 5.2 & 101.9 \pm 4.9 \\ \text { Gluconic acid } & 1.2-4.2 & 2.3-5.1 & 96.6 \pm 4.1 & 97.3 \pm 4.2 & 96.4 \pm 2.3\end{array}$




\begin{tabular}{lccccc}
\hline Succinic acid & $1.1-3.6$ & $1.6-4.5$ & $103.4 \pm 3.1$ & $97.7 \pm 2.3$ & $97.5 \pm 1.9$ \\
Glutaric acid & $1.4-3.7$ & $1.7-5.0$ & $96.3 \pm 2.1$ & $103.4 \pm 5.4$ & $102.0 \pm 2.5$ \\
Acetic acid & $0.6-3.9$ & $1.2-4.7$ & $103.2 \pm 5.1$ & $103.1 \pm 2.3$ & $99.6 \pm 3.5$ \\
Propionic acid & $1.4-4.7$ & $2.1-5.3$ & $100.5 \pm 4.5$ & $107.3 \pm 2.1$ & $101.8 \pm 1.0$ \\
Amino acids & & & & \\
Aspartic acid & $0.4-4.1$ & $1.9-5.0$ & $95.3 \pm 4.4$ & $95.6 \pm 3.9$ & $94.2 \pm 3.1$ \\
Glutamic acid & $0.9-3.6$ & $1.5-4.2$ & $104.2 \pm 3.2$ & $106.3 \pm 4.7$ & $105.5 \pm 3.4$ \\
\hline \%RSD - relative standard deviation. Results expressed as mean \pm standard deviation for accuracy. &
\end{tabular}

Source: Authors (2020).

\section{Method application}

Once the method was validated, it was applied to the analysis of AOA and amino acids in multifloral honeys from Santa Catarina state, Brazil. Figure 1 shows the electropherogram of AOA and amino acids in the H1 multifloral honey and the concentration of AOA and amino acids determined in all floral honeys was presented in Table 5.

Figure 1. Electropherogram of low molecular mass aliphatic organic acids and amino acids in the H1 multifloral honey diluted in the proportion 1:9 (w/v; honey:water). IS - internal standard (trifluoracetic acid), 1 - formic acid, 2 - citric acid, 3 - malic acid, 4 - glycolic acid, 5 - lactic acid, 6 - gluconic acid, 7 - glutamic acid, 3 unknown peak, EOF - electroosmotic flow.

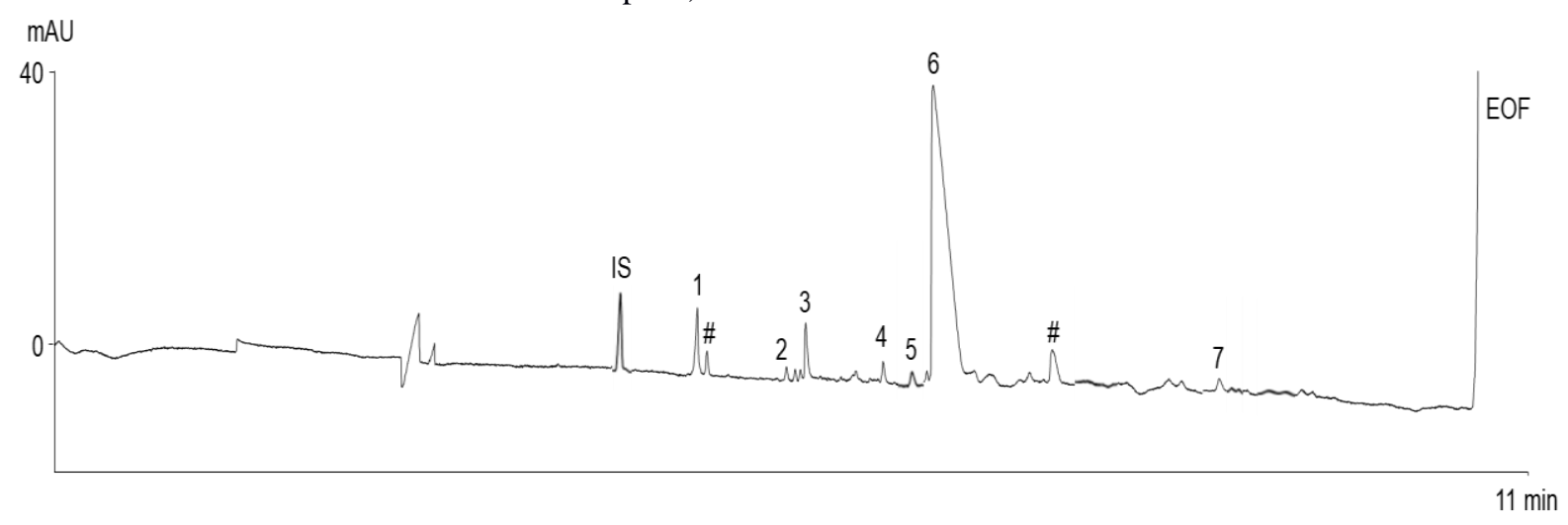

Source: Authors (2020).

Table 5. Concentration (mg $100 \mathrm{~g}^{-1}$ ) of low molecular mass aliphatic organic acids (AOA) and amino acids in multifloral honeys.

\begin{tabular}{lccccc}
\hline \multirow{2}{*}{ Compound } & \multicolumn{5}{c}{ Honey sample } \\
\cline { 2 - 6 } & $\mathrm{H} 1$ & $\mathrm{H} 2$ & $\mathrm{H} 3$ & $\mathrm{H} 4$ & $\mathrm{H} 5$ \\
\hline$A O A$ & & & & \\
Maleic acid & $<\mathrm{LOD}$ & $<\mathrm{LOD}$ & $<\mathrm{LOD}$ & $<\mathrm{LOD}$ & $<$ LOD \\
Malonic acid & $<$ LOD & <LOD & $<$ LOD & $<$ LOD & $<$ LOD \\
\hline
\end{tabular}




\begin{tabular}{|c|c|c|c|c|c|}
\hline Tartaric acid & $<\mathrm{LOD}$ & $<\mathrm{LOD}$ & $<\mathrm{LOD}$ & $<\mathrm{LOD}$ & $<\mathrm{LOD}$ \\
\hline Formic acid & $18.4 \pm 0.5$ & $8.4 \pm 0.2$ & $6.0 \pm 0.1$ & $4.3 \pm 0.0$ & $<\mathrm{LOD}$ \\
\hline Citric acid & $7.8 \pm 0.2$ & $9.7 \pm 0.3$ & $12.7 \pm 0.3$ & $22.7 \pm 0.6$ & $9.8 \pm 0.1$ \\
\hline Malic acid & $35.3 \pm 0.8$ & $6.8 \pm 0.1$ & $3.9 \pm 0.1$ & $4.1 \pm 0.1$ & $<\mathrm{LOD}$ \\
\hline Glycolic acid & $5.6 \pm 0.1$ & $5.0 \pm 0.1$ & $6.1 \pm 0.1$ & $6.6 \pm 0.1$ & $5.6 \pm 0.1$ \\
\hline Lactic acid & $8.6 \pm 0.2$ & $<\mathrm{LOD}$ & $20.4 \pm 0.2$ & $<\mathrm{LOD}$ & $<\mathrm{LOD}$ \\
\hline Gluconic acid & $674.5 \pm 18.5$ & $889.7 \pm 23.6$ & $1287.9 \pm 27.5$ & $453.7 \pm 10.7$ & $953.8 \pm 9.6$ \\
\hline Succinic acid & $<\mathrm{LOD}$ & $6.3 \pm 0.2$ & $<\mathrm{LOD}$ & $<\mathrm{LOD}$ & $6.5 \pm 0.1$ \\
\hline Glutaric acid & $<\mathrm{LOD}$ & $<\mathrm{LOD}$ & $<\mathrm{LOD}$ & $<\mathrm{LOD}$ & $<\mathrm{LOD}$ \\
\hline Acetic acid & $<\mathrm{LOD}$ & $5.9 \pm 0.1$ & $4.5 \pm 0.1$ & $<\mathrm{LOD}$ & $<\mathrm{LOD}$ \\
\hline Propionic acid & $<\mathrm{LOD}$ & $<\mathrm{LOD}$ & $<\mathrm{LOD}$ & $<\mathrm{LOD}$ & $<\mathrm{LOD}$ \\
\hline \multicolumn{6}{|l|}{ Amino acids } \\
\hline Aspartic acid & $<\mathrm{LOD}$ & $<\mathrm{LOD}$ & $<\mathrm{LOD}$ & $<\mathrm{LOD}$ & $<\mathrm{LOD}$ \\
\hline Glutamic acid & $12.4 \pm 0.3$ & $8.4 \pm 0.3$ & $5.6 \pm 0.1$ & $15.6 \pm 0.4$ & $7.6 \pm 0.1$ \\
\hline
\end{tabular}

Results expressed as mean \pm standard deviation. LOD - limit of detection.

Source: Authors (2020).

As shown in Table 5, eight AOA and one amino acid were determined in the samples, being citric, glycolic, gluconic, and glutamic acids quantified in all of them, while five AOA (maleic, malonic, tartaric, glutaric, and propionic acids) and the amino acid aspartic acid were below their limit of detection in all analyzed samples. The differences observed in the profile and amount of AOA and amino acids in the samples are possibly associated with the different botanical sources present in these honeys, since they are multifloral. Also, these honeys are from the same geographical location, which considerably reduces the influence of the site on the profile and amount of these compounds.

Gluconic acid is the main AOA found in honeys. It is formed especially by the action of the enzyme D-glucose oxidase, originated from the bee, on the glucose from the nectar (MATO et al., 2003; RUIZ-ARGÜESO; RODRIGUEZ-NAVARRO, 1973). Indeed, this AOA presented the highest concentrations in the samples evaluated and they were in agreement with those reported by other floral honeys, such as acacia, anzer flowers, rhododendron, chestnut, rosemary, thyme, heather, lavender, and multifloral, ranging from 132 to $1378 \mathrm{mg} 100 \mathrm{~g}^{-1}$ (NOZAL et al., 2003; TEZCAN et al., 2011). 
Others AOA found in the investigated honeys, such as formic, citric, succinic, and malic acids, were also reported for floral honeys from different botanical and geographical origins, and their concentrations are in many cases in agreement with these found in the present study (DEL CAMPO et al., 2016; HAROUN et al., 2012; MATYSIAK; BALCERZAK; MICHALSKI, 2018; OHMENHAEUSER et al., 2013; TEZCAN et al., 2011). Despite below the limit of detection in the honeys evaluated in the present study, maleic, malonic, tartaric, glutaric, propionic, and aspartic acids were reported in other honeys, such as sunflower, multifloral, chestnut, eucalyptus, citrus, heather, lavender, and thyme (BRUGNEROTTO et al., 2019; HAROUN et al., 2012; KIVRAK, 2015; NOZAL et al., 2003; OHMENHAEUSER et al., 2013). Therefore, AOA and amino acids can contribute in the discrimination of honeys, with high potential in the differentiation of floral and honeydew honeys (AZEVEDO et al., 2017b; HAROUN et al., 2012; SHAMSUDIN et al., 2019), but more studies still need to be conducted to ensure reliable data regarding the botanical and geographical discrimination of honeys.

It is also important to highlight the low concentration or absence of acetic acid in the samples, since this AOA is associated with fermentation process in honeys (CHIRIFE; ZAMORA; MOTTO, 2006). Therefore, the data found are strongly indicators that the evaluated honeys were fresh, especially considering that these honeys were transported, drained, and frozen immediately after harvesting the honeycomb and were handled and stored properly.

Glutamic acid is one of the main amino acids found in honeys and in floral honeys this amino acid come mainly from the pollen (BOBIS et al., 2020; CARRATÙ et al., 2011). Its concentration in the multifloral honeys evaluated in this study was in agreement with those found in the literature for other floral honeys such as sunflower, citrus, thyme, heather, lavender, vitex, jujube, and acacia, ranging from not detected to $20.5 \mathrm{mg} 100 \mathrm{~g}^{-1}$ (KIVRAK, 2015; QAMER et al., 2007; SUN et al., 2017).

\section{Conclusions}

In this study, a simultaneous method for determination of 13 AOA and two amino acids in floral honey using a capillary electrophoresis system equipped with diode array detector was validated. The proposed method showed satisfactory results for the evaluated validation parameters, ensuring the reliability in the quantification of these compounds in floral honey. Among the AOA and amino acids investigated in multifloral honeys by the validated method, eight AOA and one amino acid were determined in the samples, being citric, glycolic, gluconic, and glutamic acids quantified in all of them. Therefore, this method is suitable for use in the determination of AOA and amino acids in floral honeys. 


\section{Acknowledgments}

This study was financed in part by the Coordenação de Aperfeiçoamento de Pessoal de Nível Superior - Brasil (CAPES) - Finance Code 001. The authors also wish to thank the Conselho Nacional de Desenvolvimento Científico e Tecnológico (CNPq).

\section{References}

ARMITAGE, P.; BERRY, G.; MATTHEWS, J. N. S. Statistical methods in medical research. 4 ed. ed. Oxford, UK: Blackwell Science Ltd, 2002.

AZEVEDO, M. S. et al. Screening and determination of aliphatic organic acids in commercial Brazilian sugarcane spirits employing a new method involving capillary electrophoresis and a semi-permanent adsorbed polymer coating. Food Research International, v. 60, p. 123-130, jun. 2014.

AZEVEDO, M. S. et al. Proteome comparison for discrimination between honeydew and floral honeys from botanical specie Mimosa scabrella Bentham by principal componet analysis. Journal of The Science of Food and Agriculture, v. 97, n. 13, p. 4515-4519, 2017a.

AZEVEDO, M. S. et al. Free amino acid determination by GC-MS combined with a chemometric approach for geographical classification of bracatinga honeydew honey (Mimosa scabrella Bentham). Food Control, v. 78, p. 383-392, ago. 2017 b.

BERGAMO, G. et al. Mineral profile as a potential parameter for verifying the authenticity of bracatinga honeydew honeys. LWT, v. 97, p. 390-395, nov. 2018.

BERGAMO, G. et al. Physicochemical characteristics of bracatinga honeydew honey and blossom honey produced in the state of Santa Catarina: An approach to honey differentiation. Food Research International, v. 116, p. 745-754, fev. 2019.

BOBIS, O. et al. Eucalyptus honey: Quality parameters, chemical composition and healthpromoting properties. Food Chemistry, v. 325, n. April, p. 126870, 2020.

BRASIL. Inmetro. Instituto Nacional de Metrologia, Qualidade e Tecnologia. Orientação sobre validação de métodos analíticos. Documento de caráter orientativo. DOQ-CGCRE-008. Revisão 04. 2011.

BRUGNEROTTO, P. et al. A capillary electrophoresis method to determine aliphatic organic acids in bracatinga honeydew honey and floral honey. Journal of Food Composition and Analysis, v. 82, p. 103243, set. 2019.

CARRATÙ, B. et al. Free amino acids, oxalate and sulphate for honey characterization. Journal of ApiProduct and ApiMedical Science, v. 3, n. 2, p. 81-88, 1 abr. 2011.

CHIRIFE, J.; ZAMORA, M. C.; MOTTO, A. The correlation between water activity and \% moisture in honey: fundamental aspects and application to Argentine honeys. Journal of Food Engineering, v. 72, n. 3, p. 287-292, fev. 2006. 
DA SILVA, P. M. et al. Honey: Chemical composition, stability and authenticity. Food Chemistry, v. 196, n. April, p. 309-323, abr. 2016.

DE-MELO, A. A. M. et al. Composition and properties of Apis mellifera honey: A review. Journal of Apicultural Research, v. 57, n. 1, p. 5-37, 23 jan. 2018.

DEL CAMPO, G. et al. Quantitative determination of carboxylic acids, amino acids, carbohydrates, ethanol and hydroxymethylfurfural in honey by 1H NMR. Food Chemistry, v. 196, p. 1031-1039, abr. 2016.

DURBIN, J.; WATSON, G. S. Testing for serial correlation in least squares regression II. Biometrika, v. 38, p. 159-178, 1950.

EUROPEAN COMMISSION. European Commission Council Directive 2001/110/EC of 20 December 2001 relating to honey. Official Journal of the European Communities, p. 1047, 2002.

HAROUN, M. I. et al. Organic acid profiles and contents of Turkish honeydew and floral honeys. In: International Conference on Environment, Agriculture and Food Sciences (ICEAFS'2012). Phuket, Thailand. August 11-12, 2012., 2012.

KALJURAND, M.; KOEL, M. Recent Advancements on Greening Analytical Separation. Critical Reviews in Analytical Chemistry, v. 41, n. 1, p. 2-20, jan. 2011.

KAYGUSUZ, H. et al. Characterization of Anatolian honeys based on minerals, bioactive components and principal component analysis. LWT - Food Science and Technology, v. 68, p. 273-279, maio 2016.

KEKE, A.; CINKMANIS, I. Determination of organic acids in honey samples from Latvian market by high-performance liquid chromatography. Research for Rural Development, v. 1, p. 229-233, 2019.

KIVRAK, İ. Free amino acid profiles of 17 Turkish unifloral honeys. Journal of Liquid Chromatography \& Related Technologies, v. 38, n. 8, p. 855-862, 9 maio 2015.

KOWALSKI, S. et al. Free amino acids profile of Polish and Slovak honeys based on LCMS/MS method without the prior derivatisation. Journal of Food Science and Technology, v. 54, n. 11, p. 3716-3723, 2017.

LEVENE, H. Robust test for equality of variances. In: [s.l.] Palo Alto, USA: Stanford University Press, 1960. p. 278-292.

LUKASIEWICZ, M.; KOWALSKI, S.; MAKAREWICZ, M. Antimicrobial an antioxidant activity of selected Polish herbhoneys. LWT - Food Science and Technology, v. 64, n. 2, p. 547-553, dez. 2015.

MAGNUSSON, B.; ÖRNEMARK, U. Eurachem guide: the fitness for purpose of analytical methods - a laboratory guide to method validation and related topics. 2 ed. ed. Torino, Italy: Eurachem, 2014.

MATO, I. et al. Significance of nonaromatic organic acids in honey. Journal of Food Protection, v. 66, n. 12, p. 2371-2376, 2003. 
MATO, I. et al. Analytical Methods for the Determination of Organic Acids in Honey. Critical Reviews in Analytical Chemistry, v. 36, n. 1, p. 3-11, 12 jan. 2006a.

MATO, I. et al. Rapid determination of nonaromatic organic acids in honey by capillary zone electrophoresis with direct ultraviolet detection. Journal of Agricultural and Food Chemistry, v. 54, n. 5, p. 1541-1550, mar. 2006b.

MATYSIAK, I.; BALCERZAK, M.; MICHALSKI, R. Ion chromatography with conductometric detection for quantitation of formic acid in Polish bee honey. Journal of Food Composition and Analysis, v. 73, n. September 2017, p. 55-59, 2018.

NAVARRETE, M. et al. Direct determination of aliphatic acids in honey by coelectroosmotic capillary zone electrophoresis Direct determination of aliphatic acids in honey by coelectroosmotic capillary zone electrophoresis. Journal of Apicultural, v. 44, n. 2, p. 65$70,2005$.

NOZAL, M. J. et al. HPLC determination of low molecular weight organic acids in honey with series-coupled ion-exclusion columns. Journal of Liquid Chromatography \& Related Technologies, v. 26, n. 8, p. 1231-1253, abr. 2003.

OHMENHAEUSER, M. et al. Qualitative and quantitative control of honeys using NMR spectroscopy and chemometrics. ISRN Analytical Chemistry, v. 2013, p. 1-9, 2013.

QAMER, S. et al. Free amino acids content of Pakistani unifloral honey produced by Apis mellifera. Pakistan Journal of Zoology, v. 39, n. 2, p. 99-102, 2007.

RUIZ-ARGÜESO, T.; RODRIGUEZ-NAVARRO, A. Gluconic acid-producing bacteria from honey bees and ripening honey. Journal of General Microbiology, v. 76, p. 211-216, 1973.

SANZ, M. L. et al. A contribution to the differentiation between nectar honey and honeydew honey. Food Chemistry, v. 91, n. 2, p. 313-317, jun. 2005.

SERAGLIO, S. K. T. et al. Development and validation of a LC-ESI-MS/MS method for the determination of phenolic compounds in honeydew honeys with the diluted-and-shoot approach. Food Research International, v. 87, p. 60-67, set. 2016.

SERAGLIO, S. K. T. et al. An overview of physicochemical characteristics and healthpromoting properties of honeydew honey. Food Research International, v. 119, p. 44-66, maio 2019.

SERAGLIO, S. K. T. Mel de melato de bracatinga (Mimosa scabrella Bentham): bioacessibilidade e estabilidade química e bioativa. Universidade Federal de Santa Catarina, 2020.

SHAMSUDIN, S. et al. A comparative characterization of physicochemical and antioxidants properties of processed Heterotrigona itama honey from different origins and classification by chemometrics analysis. Molecules, v. 24, n. 21, p. 1-20, 2019.

SHAPIRO, S. S.; WILK, M. B. An analysis of variance test for normality (complete samples). Biometrika, v. 52, n. 3/4, p. 591-611, 1965.

SNEDECOR, G. W.; COCHRAN, W. G. Statistical methods. 8. ed. ed. Iowa: State 
University Press, 1989.

SUN, Z. et al. Identification of botanical origin of Chinese unifloral honeys by free amino acid profiles and chemometric methods. Journal of Pharmaceutical Analysis, v. 7, n. 5, p. 317-323, 2017.

TERZO, S.; MULÈ, F.; AMATO, A. Honey and obesity-related dysfunctions: a summary on health benefits. The Journal of Nutritional Biochemistry, v. 82, p. 108401, ago. 2020.

TEZCAN, F. et al. Evaluation of organic acid, saccharide composition and antioxidant properties of some authentic Turkish honeys. Journal of Food and Nutrition Research, v. 50, n. 1, p. 33-40, 2011. 